\title{
Advanced metastatic breast carcinoma in sickle cell disease
}

\author{
Marcellinus Uchechukwu Nwagu*, Ologo Thompson**, and Akinola Oyekemi**
}

\section{ABSTRACT}

\section{BACKGROUND}

Breast cancer is the leading cancer in women leading to over 400,000 deaths per year worldwide. It begins in the breast tissue and can metastasize to other organs if early diagnosis and treatment is not instituted. Women with sickle cell disease are usually spared from breast cancer and other solid tumours due to the tumoricidal effect of sickled erythrocytes. Breast cancers are rare among these group of patients. Despite its rare occurrence, this paper was to emphasize the need for breast cancer screening among female sickle cell disease patients who have positive family history of breast cancer.

\section{CASE DESCRIPTION}

OO was a 30-year old woman with sickle cell disease who presented to the hospital one and half years ago with a seven months history of right breast swelling and pains. She had lost her mother to breast cancer about 15 years ago. Mammography and histology of breast biopsy confirmed diagnosis of invasive ductal carcinoma of the right breast. Financial constraint was a major challenge in managing this patient as she was unable to buy her chemotherapy. She developed features suggestive of metastasis such as seizures and hepatomegaly. She was stabilized and discharged home but we lost her to follow up. She died at home.

\section{CONCLUSION}

Breast cancer is rare among females with sickle cell disease; any of them with a family history should be routinely screened for early diagnosis and treatment.

Keywords: Breast carcinoma, sickle cell disease, woman
*Department of Haematology and Blood Transfusion, Faculty of Clinical Sciences, Edo University, Iyamho, Edo State, Nigeria

**Department of Haematology and Blood Transfusion,

Faculty of Clinical Sciences, Edo University, Iyamho, Edo State, Nigeria

\section{Correspondence:}

Marcellinus Uchechukwu Nwagu Faculty of Clinical Sciences,

Edo University, Iyamho, Edo State, Nigeria

Email: unwagu@yahoo.com

Phone: +2348033851263

ORCID ID: https://orcid.org/0000-

0002-2942-4849

Date of first submission, October 22, 2018

Date of final revised submission, Apil 24, 2019

Date of acceptance, April 29, 2019

This open access article is distributed under a Creative Commons AttributionNon Commercial-Share Alike 4.0 International License

Cite this article as: Nwagu MU, Thompson $\mathrm{O}$, Oyekemi A. Advanced metastatic breast carcinoma in sickle cell disease. Univ Med 2019;38:139-43. doi: 10.18051/UnivMed.2019.v38.139-143 


\section{INTRODUCTION}

Sickle cell disease (SCD) refers to a spectrum of inherited haemoglobin disorders associated with red cell sickling in the deoxygenated state or in low oxygen tension. The presence of sickle haemoglobin (HbS) leads to the formation of sickle-shaped erythrocytes. The prevalence is highest in Africa and especially Nigeria. Other affected regions include the Middle East, Central India and countries bordering the Mediterranean Sea, especially Italy and Greece. The complications of SCD are broad and chronic in nature with affectation of virtually every body organ/system. Widely documented complications include nephropathy, retinopathy, chronic leg ulcer, heart failure, priapism, stroke, ${ }^{(1)}$ to mention but a few. A recent study in California showed an increased risk of leukemia among SCD patients but reduced risk of solid tumours. ${ }^{(2)}$

Breast carcinoma is a cancerous growth that begins in the breast tissues. It is the most common cancer in women with an annual incidence of about 1 million ${ }^{(3)}$ and more than 500,000 women died in 2011 due to breast cancer. ${ }^{(4)}$ As of January 2019, there are more than 3.1 million women with a history of breast cancer in the United States. ${ }^{(5)}$

In Nigeria, about $15 \%$ of cancer-related deaths is due to breast cancer, making it the leading cause of cancer-related deaths among Nigerian women. ${ }^{(6,7)}$ Risk factors associated with breast cancer include female gender, increasing age, family history (especially mothers and siblings), early menarche or late menopause, overweight, prolonged oestrogen exposure and use of oral contraceptive pills, not having children or having children after 35 years. ${ }^{(6)}$

Breast cancer, even though very common in women, is not usually seen in women with sickle cell disease because of the reason earlier mentioned. This case is reported to draw attention of medical practitioners and healthcare providers to the need for vigilance and caution in respect of breast cancer among sickle cell disease patients. For every female SCD patient, attention should be paid towards detailed family history, as a positive family history is a strong associated factor for breast cancer. This would create room for routine screening, early diagnosis and timely treatment.

\section{CASE REPORT}

Ms OO was a 30-year old woman with SCD patient who presented to the Surgical outpatient clinic of Delta State University Teaching Hospital (Delsuth) on $15^{\text {th }}$ of May 2017 with complaints of right breast swelling, right breast pain, and right axillary swelling of 7 months duration. Her menarche was at the age of 13 years and she was not on oral contraceptive pills. Her mother died 15 years ago to breast cancer.

Physical examination revealed a young woman who was pale and jaundiced with right axillary lymphadenopathy. There was a nontender mass on the right breast measuring $3 \mathrm{~cm}$ $\mathrm{x} 5 \mathrm{~cm}$ that was associated with skin dimpling and nipple retraction but showed no nipple discharge. Mammography showed features of right breast malignancy (Figure 1).

Histology (730 x 550 magnification) showed a stained Haematoxylin and Eosin section of breast tissue (Figure 2). It consists of invading sheets of tumor cells having moderate nuclear pleomorphism in a desmoplastic stroma. In a focus are malignant neoplastic cells penetrating through the duct wall. Within its supporting stroma are few dysplastic cells. The patient was counselled on various treatment modalities. Due to lack of funds she could not procure chemotherapeutic agents and was therefore discharged against medical advice. She was lost to follow up until two months later when she was rushed back to the hospital with severe bone pains /vaso-occlusive crisis. She was markedly pale, jaundiced with a hepatomegaly of $9 \mathrm{~cm}$ below the right costal margin. She had one episode of seizures. Abdominal ultrasound revealed hepatomegaly with hepatic metastasis 


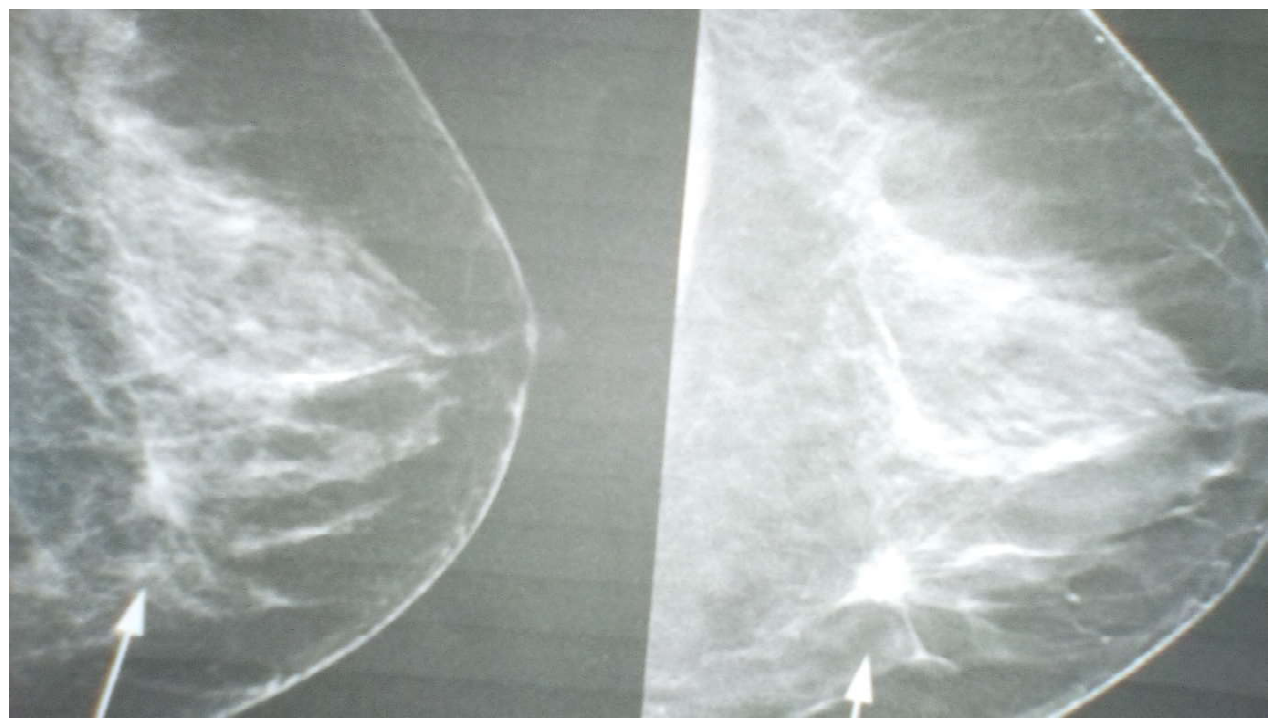

Figure 1. Mammography of right breast.

Showing abnormal breast tissue. Note the (arrowed) area of white and high-density tissue

from the breast primary. Electrolytes showed hyponatremia (sodium $125 \mathrm{mmol} / \mathrm{L}$ ) and hypokalemia (potassium $2.8 \mathrm{mmol} / \mathrm{L}$ ). She was stabilized and discharged from hospital. Patient was lost again to follow up. She died at home!

\section{DISCUSSION}

Sickle cell disease is associated with many systemic complications which ultimately lead to increased morbidity and mortality with reduced life expectancy. No work has been done to determine the incidence of cancer in SCD patients compared to the general Nigerian population. However, a study in California, USA, showed that SCD patients had a $72 \%$ increased risk of haematologic malignancies and a $38 \%$ reduced risk of solid tumours, with lower risk of breast cancer and male genital cancers (prostate, testis, penis, and other male genital organs). ${ }^{(2)}$ The characteristic pathologic features of SCD include chronic inflammation, increased

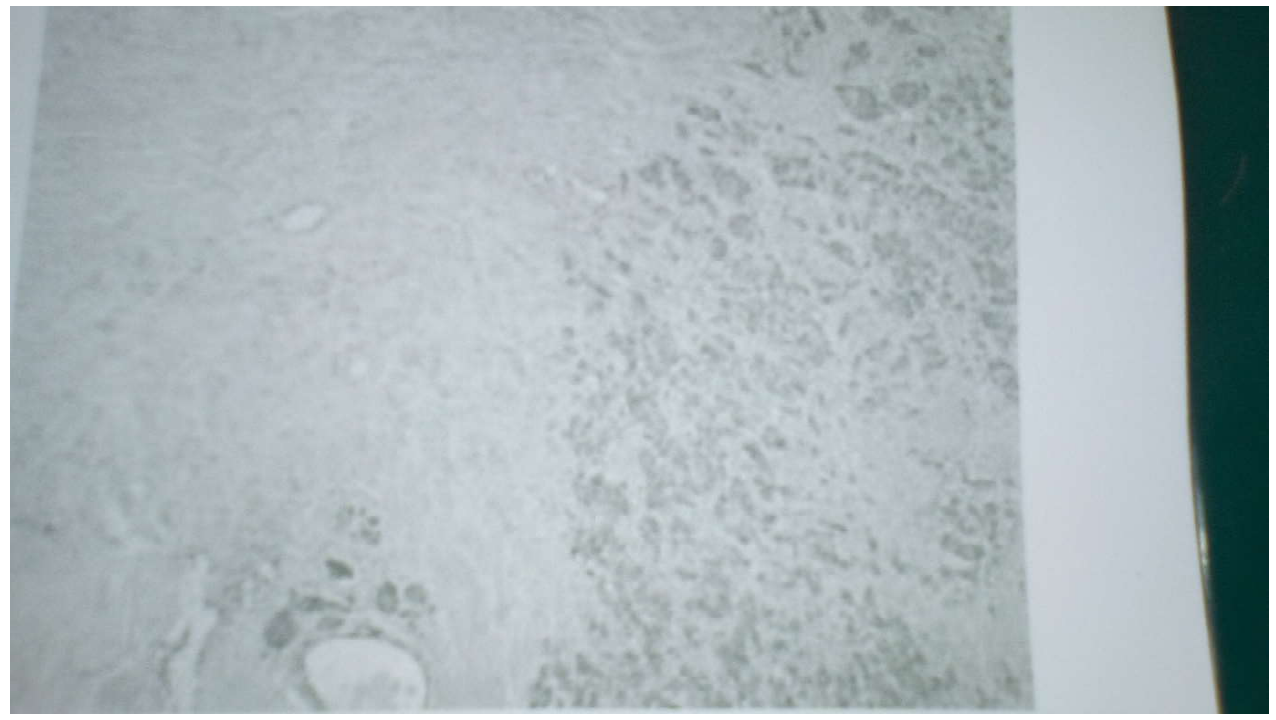

Figure 2. Histology: invasive ductal carcinoma

Showing breast tissue with abnormal malignant neoplastic cells penetrating through the duct wall into the stroma 
susceptibility to infections, iron overload from multiple transfusions, erythroid hyperplasia and bone marrow cellular turnover. Studies have shown that these identified factors play a multidimensional role in cancer development. ${ }^{(8-12)}$ These common complications may explain the increased risk of leukemia. However, the $38 \%$ reduced risk of solid tumours can be explained from the sickling of the red blood cells. ${ }^{(13)}$ Terman et al. ${ }^{(13)}$ applied sickle-shaped erythrocytes to target oxygen-deprived breast cancer cells in infected mice. They found that sickled erythrocytes occluded the blood vessels surrounding the tumour. Sickled erythrocytes may be acting as anti-angiogenic agents and thus inhibiting solid tumour formation. This patient had seizures which is not uncommon in SCD patients. The seizure in our patient was aborted using diazepam injections. The cause of seizure in this patient could be due to electrolyte changes especially hyponatremia which was seen in this patient. It could also be due to metastasis of cancer cells to the brain from the breast. About $15-30 \%$ of patients with metastatic breast cancer will develop brain metastases. ${ }^{(14)}$ Electrolytes showed hyponatremia and hypokalemia which were corrected with full-strength Darrow's solution and normal saline. The patient was also transfused with 2 units of packed red blood cells. Limitations in managing this patient revolved around financial constraints. SCD, on its own, has been established to cause an enormous financial burden on parents and households. ${ }^{(15)}$

The patient was unable to procure chemotherapeutic agents leading to worsening of the disease and eventual metastasis. With appropriate chemotherapy, breast cancer in sickle cell disease could be well managed with minimal side effects to the patient. ${ }^{(16)}$ Again, lack of funds was a hindrance to carrying out a brain computed tomography (CT) or magnetic resonance imaging (MRI) to confirm brain metastasis. Other investigations we would have loved to do such as immunohistochemistry was also thwarted by financial constraints. Lack of funds is a humanitarian issue of public health significance that needs to be addressed by government and relevant authorities. The National Health Insurance Scheme (NHIS) would be of tremendous assistance in this regard; unfortunately more than $70 \%$ of Nigerians are yet to register with the scheme. ${ }^{(17)}$

The National Health Insurance Scheme (NHIS) was established under Act 35 of 1999 by the Federal Government of Nigeria to improve the health of all Nigerians at an affordable cost.

All efforts should be made by necessary government agencies to increase the awareness of the populace and encourage them to enrol into the health insurance scheme. Agencies such as National Orientation Agency, established in 2005 , can do a lot in this regard. There was a family history of breast cancer in the index case making the patient to be at high risk of breast cancer. ${ }^{(18)}$ Routine screening methods such as self breast examination, mammography and breast sonography could have assisted in early diagnosis and prevention of late disease.

\section{CONCLUSION}

Solid tumours such as breast cancer is not common in female patients with SCD when compared with the general population. Routine breast cancer screening methods are necessary and should be recommended to those patients with high risk of breast cancer such as positive family history.

\section{CONFLICT OF INTEREST}

There is no conflict of interest.

\section{ACKNOWLEDGEMENT}

We thank the technical staff of the Departments of Anatomic Pathology and Radiology for their assistance in providing the histology slides and mammographs, respectively. 


\section{CONTRIBUTORS}

MUN contributed to writing the manuscript and retrieving the histology slides and mammographs from the concerned departments. OT retrieved the case file from the records department and wrote the summary of the case. AO made a substantial modification to the manuscript and added some references. All authors have read and approved the final manuscript.

\section{REFERENCES}

1. Nwagu MU. Sickle cell disease: review of complications, current and emerging trends in management. Ebonyi Med J 2011; 10:84-92.

2. Brunson A, Keegan THM, Bang H, et al. Increased risk of leukemia among sickle cell disease patients in California. Blood 2017;130:1597-9 . doi: 10.1182/ blood-2017-05-783233.

3. Ghoncheh M, Pournamdar Z, Salehiniya H. Incidence and mortality and epidemiology of breast cancer in the world. Asian Pac J Cancer Prev 2016; 17:43-6.

4. World Health Organization. Global health estimates. Geneva: World Health Organization; 2013.

5. Breastcancer.org. U.S breast cancer statistics. Ardmore, PA. US; Breastcancer.org;2019.

6. Osaro E. Breast cancer in Nigeria: diagnosis, management and challenges. Bloomington, IN, USA: Author House;2016.

7. Okobia MN, Bunker CH, Okonofua FE, et al. Knowledge, attitude and practice of Nigerian women towards breast cancer: a cross-sectional study. World J Surg Oncol 2006;4:11-5.

8. Kundu JK, Surh YJ. Emerging avenues linking inflammation and cancer. Free Radic Biol Med 2012;52:2013-37. doi: 10.1016/j.freeradbiomed. 2012.02.035
9. Crusz SM, Balkwill FR. Inflammation and cancer: advances and new agents. Nat Rev Clin Oncol 2015;12: 584-96. doi: 10.1038/nrclinonc.2015.105.

10. Aggarwal BB, Shishodia S, Sandur SK, et al. Inflammation and cancer: how hot is the link? Biochem Pharmacol 2006;72:1605-21.

11. Chung WS, Lin CL, Lin CL, et al. Thalassaemia and risk of cancer: a population-based cohort study. J Epidemiol Community Health 2015;69:1066-70. doi : 10.1136/jech-2014-205075.

12. Zacharski LR, Chow BK, Howes PS, et al. Decreased cancer risk after iron reduction in patients with peripheral arterial disease: results from a randomized trial. J Natl Cancer Inst 2008;100:996-1002.

13. Terman DS, Viglianti BL, Zennadi R, et al. Sickle erythrocytes target cytotoxics to hypoxic tumor microvessels and potentiate a tumoricidal response. PLoS One 2013;8:e52543. doi: 10.1371/ journal.pone.0052543.

14. Tabouret E, Chinot O, Metalus P, et al. Recent trends in the epidemiology of brain metastasis: an overview. Anticancer Res 2012;32:4655-62.

15. Olatunwa $\mathrm{O}$, Ogundare EO, Fadare J. The financial burden of sickle cell disease on households in Ekiti, Southwest Nigeria. Clinicoecon Outcomes Res 2015;7:545-53. doi: 10.2147/CEOR.S86599.

16. Al Zaman AS. Breast cancer in patients with sickle cell disease can be treated safely with weekly paclitaxel. Saudi Med J 2013;34:199-201.

17. Brown BJ, Okereke JO, Lagunju IA, et al. Burden of health-care on carers of children with sickle cell disease in Nigeria. Health Soc Care Community 2010;18:289-95. doi: 10.1111/j.1365-2524.2009. 00903.x.

18. Boyd NF, Martin LJ, Yaffe MJ, et al. Mammographic density and breast cancer risk: current understanding and future prospects. Breast Cancer Res 2011;13:223. doi: 10.1186/ bcr2942. 